\title{
Classic Kaposi's sarcoma treated with elastic stockings and outpatient follow-up of a 90 -year-old patient
}

\author{
Sarcoma de Kaposi clássico tratado com meias elásticas e acompanhamento \\ ambulatorial numa paciente de 90 anos
}

\author{
Flavia Trevisan ${ }^{1}$ \\ Clovis Antonio Lopes Pinto ${ }^{3}$
}

\author{
Paulo Rowilson Cunha \\ Celia Antonia Xavier de Moraes Alves ${ }^{4}$
}

DOI: http://dx.doi.org/10.1590/abd1806-4841.20132104

\begin{abstract}
Kaposi's sarcoma is a multifactorial angioproliferative disorder. The herpes virus 8 human contributes to its pathogenesis, but it is uncertain whether these lesions are only reactive hyperplasia to the virus or neoplasia. Four clinical types are described: classic, endemic, iatrogenic and HIV-associated. Classic Kaposi's sarcoma has no standard staging or treatment protocols. Some studies have shown the use of compression stockings in the treatment of lymphedema associated with Kaposi's sarcoma. We report the case of a 90 year-old patient with classic Kaposi's sarcoma treated with compression stockings who showed a satisfactory response.
\end{abstract}

Keywords: Residential treatment; Sarcoma, Kaposi; Stockings, compression; Treatment Outcome

Resumo: O sarcoma de Kaposi é uma desordem angioproliferativa de causa multifatorial. O vírus herpes 8 participa na sua patogenia, porém há dúvidas se a origem das lesões é apenas por hiperplasia reacional ao vírus ou uma neoplasia propriamente dita. Quatro tipos clínicos são descritos: clássico, endêmico, iatrogênico e associado ao HIV. O tipo clássico de sarcoma de Kaposi mantém-se sem padronização de estadiamento ou protocolos de tratamento. Há alguns estudos mostrando o uso de meias compressivas no tratamento do linfedema associado ao Kaposi Comunicamos um caso de uma paciente de 90 anos com sarcoma de Kaposi clássico tratado com meias elásticas compressivas, mostrando uma resposta satisfatória.

Palavras-chave: Meias de compressão; Resultado de tratamento; Sarcoma de Kaposi; Tratamento domiciliar

\section{INTRODUCTION}

Kaposi's sarcoma is a cell proliferation of vascular origin related to the herpes virus type 8 human, with the classic type being extremely rare..$^{1-3}$ Its clinical symptoms vary. It is sometimes associated with lymphedema and usually indolent, without dissemination. ${ }^{1-4}$ We report a case of classic Kaposi's sarcoma affecting the lower limbs of an elderly female patient, diagnosed promptly and treated with elastic stockings, evolving with satisfactory subjective and objective results.

\section{CASE REPORT}

Female patient, 90 years old, of Italian descent, presented with a history of maculo-papular, nodular, violaceous lesions in the middle third of her left leg for two years, associated with swelling and heaviness in her lower limbs. With the suspicion of Kaposi's sarcoma, biopsy was performed, and the diagnosis was confirmed by histology and immunohistochemistry. The fact that she was HIV-negative and had no history of exogenous immunosuppression led to the diagnosis of classic Kaposi's sarcoma.

Approved by the Advisory Board and accepted for publication on 23.10.2012

* Study conducted at the School of Medicine of Jundiaí (FMJ) - Jundiaí (SP), Brazil.

Conflict of interest: None

Financial funding: None

MD - Resident of Dermatology, School of Medicine of Jundiaí (FMJ) - Jundiaí (SP), Brazil.

Professor - Head of the Service of Dermatology, School of Medicine of Jundiaí (FMJ) - Jundiaí (SP), Brazil.

PhD - Professor of Pathology, School of Medicine of Jundiaí (FMJ) and pathologist at Hospital AC Camargo - Liberdade (SP), Brazil.

M.Sc. - Professor of Dermatology, School of Medicine of Jundiaí (FMJ) - Jundiaí (SP), Brazil. 
We decided to use medium compression stockings and periodically monitored the patient. Results were satisfactory after 20 months. Although the total area affected increased, there was a significant improvement of the edema, discrete reduction of lesion volume, which changed from plaques and nodules to macules, and the patient reported a marked improvement of the symptoms (Figure 1).
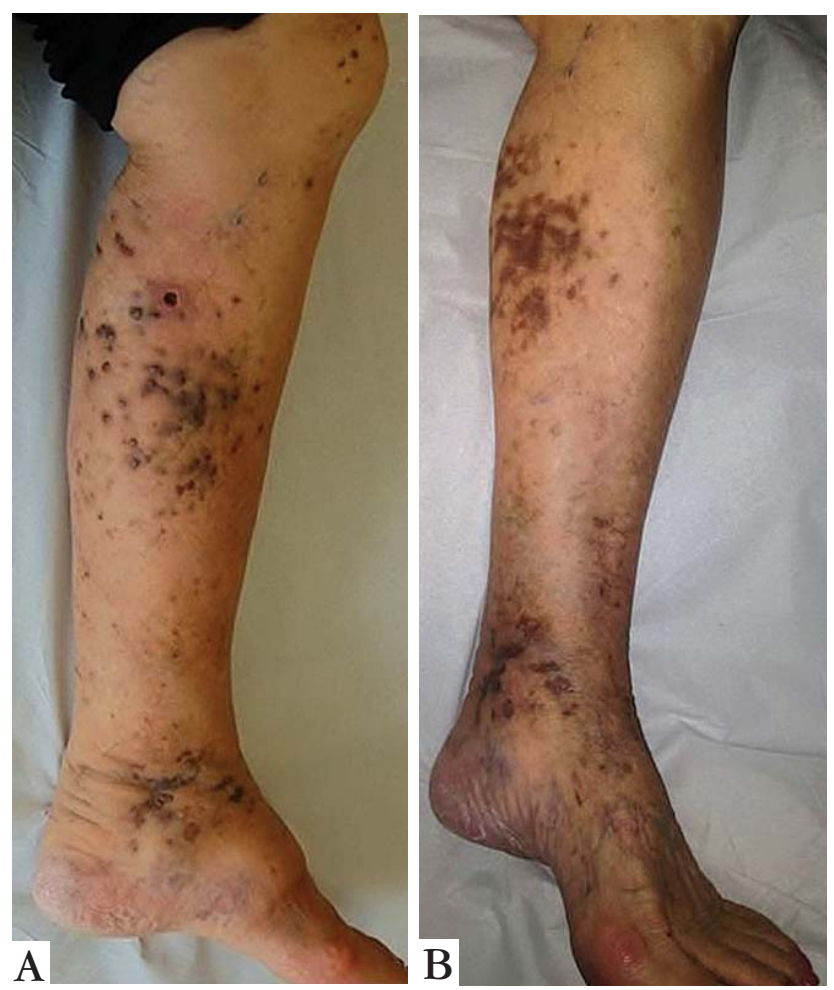

Figure 1: classic Kaposi's sarcoma. A: Initial dermatologic examination of the medial aspect of the left leg. B: Dermatologic examination after 20 months of correct use of elastic stockings of medium compression with significant reduction of leg edema and lesion volume, evolving from nodules to macules

\section{DISCUSSION}

First described by Moritz Kaposi as multiple pigmented sarcoma involving the skin, classic Kaposi's sarcoma is a rare disease. The highest prevalence rates of the disease are found in elderly men from Mediterranean countries; it affects approximately 1:30,000 individuals in the Italian islands, following the prevalence of the herpes virus type 8 human. ${ }^{1,4}$ It has a multifactorial development and its pathogenesis involves the processes of angiogenesis, inflammation and proliferation of spindle cells. ${ }^{1}$

Clinically, it varies from macules and papules to purpuric, purplish or blackish nodules in the lower limbs, often with lymphedema due to infiltration and dermal lymphatic involvement. It shows an indolent clinical course, rarely evolving to metastases. When they occur, they are mostly asymptomatic and affect the gastrointestinal tract, which makes the endoscopic procedure unnecessary and useless for prognosis. ${ }^{3}$

After clinical suspicion, diagnosis is confirmed by histology. Immunohistochemistry and PCR may help in doubtful cases. Other tests such as endoscopy and ultrasound are recommended based on each case. ${ }^{3}$ Benign vascular tumors, acroangiodermatitis, bacillary angiomatosis and sporotrichosis are some of the differential diagnoses for the disease. ${ }^{1,2}$

One way of staging suggested in the literature divides Kaposi's sarcoma into four clinical types maculo-nodular, infiltrative, florid and disseminated. Each one of them is divided into slow or fast, depending on the speed of progression and presence or absence of complications (Table 1). ${ }^{2}$ Based on this evaluation, a conservative treatment is restricted to the maculo-nodular type. Local treatment would be reserved for the maculo-nodular and infiltrative types, the latter being slow-evolving and without complications. For all other cases or when there is visceral involvement, systemic treatment is indicated.

TABLE 1: Staging of classic Kaposi's sarcoma

\begin{tabular}{|c|c|c|c|c|c|}
\hline & Lesions & Location & Behavior & Evolution & Complications \\
\hline \multirow[t]{2}{*}{ I } & Nodules / macules & Legs & Nonaggressive & A - slow & Lymphedema \\
\hline & & & & B - fast & Lymphorrhea \\
\hline \multirow[t]{2}{*}{ II } & Plaques & Legs & Locally aggressive & A - slow & \\
\hline & & & & B - fast & Hemorrhage \\
\hline \multirow[t]{2}{*}{ III } & Angiomatous plaques and nodules & Limbs & Locally aggressive & A- slow & Functional damage \\
\hline & & & & B - fast & \\
\hline IV & Angiomatous plaques and nodules & Limbs, trunk, head & Disseminated & B - fast & Ulceration \\
\hline
\end{tabular}


Local treatment includes topical imiquimod, cryotherapy, laser, surgical excision, radiotherapy and intralesional chemotherapy. ${ }^{1-5}$ Several studies have shown great radiosensitivity of this type of sarcoma with a good response to radiotherapy, ${ }^{6,7}$ The effectiveness of the use of compression stockings, described by Brambilla et al. in a study of 65 patients with Kaposis's sarcoma below the knees, was seen primarily in the treatment of lymphedema associated with sarcoma. ${ }^{4}$ The first choice for systemic treatment is pegylated liposomal doxorubicin., ${ }^{3,5}$ Other chemotherapeutic agents, either alone or in combination, and immunomodulators such as interferon-alpha recombinant or thalidomide can be used. ${ }^{7}$ Some therapies under investigation are antivirals such as valganciclovir, inhibitors of vascular growth factor receptor and tyrosine kinase, metalloproteinase, monoclonal antibody therapy, protease inhibitors, and mTOR inhibitors. ${ }^{5,8}$

We have described a case of CKS treated effectively with only compression stockings, bringing clinical improvement and quality of life to the patient. We questioned the effectiveness of the improvement of venous circulation, not only in the reduction of edema, but also in the increase of tissue oxygenation, thus reducing the stimulation and production of angiogenic factors, which participate in the pathophysiological basis of the disease.

\section{REFERENCES}

1. Krown SE, Singh JC. Classic Kaposi's sarcoma: clinical features, stagings, diagnosis, and treatment. UptoDate, [Internet]. 2011 [cited 2011 Feb 16]. Available from: http://www.uptodate.com

2. Brambilla L, Boneschi V, Taglioni M, Ferrucci S. Staging of classic Kaposi's sarcoma: a useful tool for therapeutic choices. Eur J Dermatol. 2003;13:83-6.

3. Casper C. New Approaches to the Treatment of Human Herpesvirus 8 - Associated Disease. Rev Med Virol. 2008;18:321-9.

4. Brambilla L, Tourlaki A, Ferrucci S, Brambati M, Boneschi V. Treatment of classic Kaposi's sarcoma-associated lymphedema with elastic stockings. J Dermatol. 2006;33:451-6.

5. Cancer.org [homepage on the Internet]. National Cancer Institute. Classic Kaposi Sarcoma - Current Clinical Trials. 2009. [cited Feb 2011 18]. Available from: www.cancer.gov.

6. Mukai MM, Chaves T, Caldas L, Neto JF, Santamaría JR. Primary Kaposi's sarcoma of the penis. An Bras Dermatol. 2009;84:524-6.

7. Costa IMC, Menezes FG, Hajjar LA, Salaro CP, Matos RMC. Classic Kaposi's sarcoma: a case report. An Bras Dermatol, 2001;76:195-9.

8. Stebbing J, Portsmouth S, Gotch F, Gazzard B. Kaposi's sarcoma - an update. Int J STD AIDS. 2003;14:225-7.

\author{
MAILING ADDRESS: \\ Flavia Trevisan \\ Rua Francisco Telles, 250 - Vila Arens \\ 13202-250 - Jundiaí - SP \\ Brazil \\ E-mail: flaviatrevisan1@yahoo.com.br
}

How to cite this article: Trevisan F, Cunha PR, Pinto CAL, Alves CAXM. Classic Kaposi's sarcoma treated with elastic stockings and outpatient follow-up of a 90-year-old patient. An Bras Dermatol. 2013, 88(6 Suppl 1):S200-2. 